\title{
Evaluation of Quality Protein Maize (Zea mays L) Hybrids at Jimma, Western-Ethiopia
}

\author{
Aman $\mathrm{J}^{1}$, Bantte $\mathrm{K}^{2}$, Alamerew $\mathrm{S}^{2}$ and Tolera $\mathrm{B}^{3 *}$ \\ ${ }^{1}$ Mekele Institute of Technology, Sugarcane Micropropagation project, Mekelle, Ethiopia \\ 2Jimma University, College of Agriculture and Veterinary Medicine, Jimma, Ethiopia \\ ${ }^{3}$ Ethiopian Sugar Corporation Research and Training Division Biotechnology Research Team, Wonji, Ethiopia
}

\begin{abstract}
Maize is an important food crop in Ethiopia. But its nutritional quality is poor as its seed protein is devoid of two essential amino acids (lysine and tryptophan). The objective of the present study was to evaluate the performance of Quality Protein Maize (QPM) hybrids developed by CIMMYT. Forty three QPM hybrids and 2 checks were tested using 5 X9 alpha lattice design with two replications. Data were subjected to ANOVA using SAS version 9.2. The ANOVA revealed very highly significant differences among the genotypes $(p<0.001)$, for $50 \%$ tasseling, ear height, plant count and grain yield. High phenotypic variances were observed for ear height, number of rows/ear, number of grains/row and grain yield. The phenotypic coefficient of variation and genotypic coefficient of variation were high for ear height, plant count, number of rows/ear, number of grains/row and grain yield. The maximum (0.91) and minimum (0.23) broad sense heritability's were recorded for number of rows/ear and days to $50 \%$ tasseling respectively.
\end{abstract}

Keywords: Quality protein Maize (QPM); Phenotypic variability; Genotypic variability; Heritability

\section{Introduction}

Zea mays L. (Family Poaceae; Subfamily Panicoideae; Genus Zea) is an important annual food crop of the world. Z. mays L. (maize) is one of the five species in Genus Zea, the others being $Z$. diploperennis $\mathrm{HH}, Z$. luxurians, Z. nicaraguensis $\mathrm{HH}$, and Z. perennis (United States Department of Agriculture [1]. The species of Zea have chromosome number of $2 n=20$; except $Z$. perennis with $2 n=40$ [2]. Maize occupies an important position in the world economy and trade as a food, feed and an industrial grain crop. Several million people in the developing world including Ethiopia consume maize as a principal staple food and derive their protein and calorie requirements from it. The grain accounts for about 15 to $56 \%$ of the total daily calories in diets of people in several developing countries in Africa and Latin America, where animal protein is scarce and expensive [3]. In Ethiopia, it is produced for food among low-income families served in different forms of dishes. It is also used in the production of traditional alcoholic beverages for household consumption and family-based businesses. The leaf and stalk are used for animal feed while dried stalk and ear are used for fuel.

Although several hundred million people rely on maize for their principal daily food and for feeding their livestock, it lacks the full range of essential amino acids, namely lysine and tryptophan needed to produce proteins [4]. Until the early 1970s, protein deficiency was believed to be the most serious cause of malnutrition for people who use maize as their principal staple food. In 1963, scientists at Purdue University discovered a mutant maize variety, named as Opaque-2, with twice the normal levels of lysine together and elevated levels of tryptophan [5]. The discovery of Opaque-2 was heralded as a significant breakthrough in the global alleviation of protein deficiency. The genetic system that confers high levels of lysine and tryptophan in maize endosperm protein is the recessive allele of the Opaque-2 gene mapped to short arm of chromosome 7 of maize [6]. The improved protein quality of maize mutants is due to repression of zein synthesis thus increase in non-zein fraction yielding increased lysine and tryptophan [7]. Hence, though this mutant aroused tremendous interest and enthusiasm for its possible use in developing maize with superior protein quality, the pleiotropic effects of such mutations began to be recognized. The trait was found to be closely associated with several undesirable ones. The Opaque-2 maize kernels were dull and chalky, had $15-20 \%$ less grain weight and were more susceptible to several diseases and insects [8] leading to the loss of interest towards it among scientists. Fortunate enough, few international researchers had continued their systematic research activities on refining the original Opaque- 2 variety with the aim of maintaining its nutritional quality while making it competitive with conventional varieties of improved maize. And over time, breeders in the International Maize and Wheat Improvement Center (CIMMYT) found modifier genes that restored the desirable hard endosperm phenotype in materials containing the recessive Opaque- 2 mutation. These agronomically acceptable and nutritionally enhanced materials later came to be known as Quality Protein Maize (QPM) [9-11]. QPM contains nearly twice as much usable protein as other maize grown in the tropics and yields $10 \%$ more grain than traditional varieties of maize [12].

Despite its importance, the cultivation and use of QPM is not expanding throughout the world including in Ethiopia. This is mainly due to poor adaptation of QPM lines in different agroecological conditions of the world. The best option of utilizing the QPM germplasm is carrying out different adaptation trials of the QPM hybrids developed by CIMMYT and other research groups to select high performing and stable materials for a given agro-ecology. In Ethiopia, there are few QPM hybrids that perform well, namely:

${ }^{*}$ Corresponding author: Tolera B, Ethiopian Sugar Corporation Research and Training Division Biotechnology Research Team, Wonji, Ethiopia, Tel: 251-910181644; E-mail: belaytolera@yahoo.com

Received November 17, 2015; Accepted December 21, 2015; Published January 01,2016

Citation: Aman J, Bantte K, Alamerew S, Tolera B (2016) Evaluation of Quality Protein Maize (Zea mays L) Hybrids at Jimma, Western-Ethiopia. J Forensic Anthropol 1: 101.

Copyright: ( 2016 Aman J, et al. This is an open-access article distributed under the terms of the Creative Commons Attribution License, which permits unrestricted use, distribution, and reproduction in any medium, provided the original author and source are credited. 
Citation: Aman J, Bantte K, Alamerew S, Tolera B (2016) Evaluation of Quality Protein Maize (Zea mays L) Hybrids at Jimma, Western-Ethiopia. J Forensic Anthropol 1: 101

BHQP-542 [13], Gibessa, BHQ-542 [14], BHQPY-545 and Melkassa6Q [15]. All are released to farmers and are benefitting them. However, these activities alone do not suffice in answering the nutritional needs of a large sector of the Ethiopian people who principally depend on maize for staple food. Hence, it is necessary and helpful to evaluate the different QPM hybrids. And yet, very little has been done in evaluating QPM hybrids in Ethiopia. This paper reports the findings of a study aiming at evaluating the performance of CIMMYT's QPM experimental hybrids in Jimma, Western Ethiopia.

\section{Materials and Methods}

\section{Description of study area}

The experiment was conducted between July and October 2009 at the research field of Jimma University College of Agriculture and Veterinary Medicine called Eladalle (altitude: $1722 \mathrm{~m}$; latitude: $7^{\circ} 33^{\prime \prime}$ $0^{\prime} \mathrm{N}$; longitude: $36^{\circ} 57^{\prime \prime} 0^{\prime} \mathrm{E}$ ). Eladalle has: (a) mean maximum and minimum annual temperatures are $26.8^{\circ} \mathrm{C}$ and $11.4^{\circ} \mathrm{C}$, respectively; (b) mean maximum and minimum relative humidity in the area are $91.4 \%$ and $39.92 \%$, respectively; (c) mean annual rainfall of $951.5 \mathrm{~mm}$; and (d) reddish-brown clay soil with $\mathrm{pH}$ ranging from 5.07 to 6.0 [16].

\section{Experimental materials}

QPM hybrids obtained from CIMMYT were used in the study. The materials consisted of 43 three way hybrids and two checks (one commercial and another local). Details of materials are shown in Table 1.

\section{Experimental designs and procedure}

The materials were sown in alpha lattice $(5 \times 9)$ with 5 plots per block with two replications in a 5 meters single row plot with spacing of 0.75 meters between rows, and 0.3 meters between plants. Though it may be argued that the number of replications is small, the efficiency of alphalattice design increases precision of the experiment. All agronomic practices including land preparation, weeding, and fertilization were applied to all plots as per standard practices for maize.

\section{Data sources}

Data were collected on the whole plot basis for days for 50 percent tasseling, plant count and grain yield, whereas plant height, ear height, number of kernels row/ear and numbers of kernels per row were taken on the basis of five randomly selected plants and 100-kernel weight was also taken from composite seeds of all the plants from the plot after removing the plants at the ends of the rows.

\section{Data analysis}

Data collected for each trait were analyzed using ANOVA using SAS Software, Version 9.2 [17]. Least significant difference (LSD) was employed in comparing the means. Phenotypic and genotypic variances; and phenotypic and genotypic coefficients of variations were computed using GENRES Version 7.01 [18].

\section{Grain yield}

The grain yield was adjusted to a uniform moisture level i.e., $15 \%$. The following formula were used to convert this yield in $\mathrm{kg} / \mathrm{ha}$.

Yield $=$ Fresh Weight $\times\left[\frac{100-\text { Moisture }}{100}\right] \times\left[\frac{1.176 \times 0.8 \times 100}{\text { Plot Size in } m^{2}}\right]$

Plot size being $3.75 \mathrm{~m}^{2} ; 1.176$ is constant, 0.8 is shelling ratio,

\section{Heritability in the broad sense}

Since the experiment was conducted in single location, Heritability in the Broad Sense was calculated using GENRES based on components of variance as:

$$
H^{2}=\frac{\delta^{2} g}{\delta^{2} p} \times 100
$$

\begin{tabular}{|c|c|c|c|c|c|}
\hline Entry & Name & Origin & Entry & Name & Origin \\
\hline 1 & CKH-08001: & KB08B-0B20-1/2 & 24 & $\mathrm{CKH}-08024$ & KB08A-0A51-19/20 \\
\hline 2 & CKH-08002: & KB08B-0B20 21/22 & 25 & CKH-08025 & KB08A-0A51-21/22 \\
\hline 3 & CKH-08003 & KB08B-0B20-23/24 & 26 & CKH-08026 & KB08A-0A51-29/30 \\
\hline 4 & CKH-08004 & KB08B-0B20-27/28 & 27 & CKH-08027 & KB08A-0A51-31/32 \\
\hline 5 & CKH-08005 & KB08B-0B20-31/32 & 28 & $\mathrm{CKH}-08028$ & KB08A-0A51-35/36 \\
\hline 6 & CKH-08006 & KB08B-0B20-33/34 & 29 & CKH-08029 & KB08A-0A51-37/38 \\
\hline 7 & CKH-08007 & KB08B-0B20-35/36 & 30 & $\mathrm{CKH}-08030$ & KB08A-0A51-43/44 \\
\hline 8 & CKH-08008 & KB08B-0B20-39/40 & 31 & $\mathrm{CKH}-08031$ & KB08A-0A51-51/52 \\
\hline 9 & CKH-08009 & KB08B-0B20-41/42 & 32 & CKH-08032 & KB08A-0A51-53/54 \\
\hline 10 & CKH-08010 & KB08B-0B20-45/46 & 33 & $\mathrm{CKH}-08033$ & KB08A-0A49-9/10 \\
\hline 11 & CKH-08011 & KB08B-0B20-47/48 & 34 & CKH-08034 & KB08A-0A49-17/18 \\
\hline 12 & CKH-08012 & KB08B-0B20-49/50 & 35 & $\mathrm{CKH}-08035$ & KB08A-0A49-21/22 \\
\hline 13 & CKH-08013 & KB08B-0B20-51/52 & 36 & CKH-08036 & KB08A-0A49-23/24 \\
\hline 14 & CKH-08014 & KB08B-0B20-55/56 & 37 & $\mathrm{CKH}-08037$ & KB08A-0A49-25/26 \\
\hline 15 & CKH-08015 & KB08B-0B20-59/60 & 38 & CKH-08038 & KB08A-0A49-41/42 \\
\hline 16 & CKH-08016 & KB08B-0B20-61/62 & 39 & CKH-08039 & KB08A-0A49-43/44 \\
\hline 17 & CKH-08017 & KB08A-0A51-1/2 & 40 & CKH-08040 & KB08A-0A49-27/28 \\
\hline 18 & CKH-08018 & KB08A-0A51-3/4 & 41 & QPMHYB1 & KB07B-0B37-1/2 \\
\hline 19 & CKH-08019 & KB08A-0A51-5/6 & 42 & QPMHYB2 & KB07B-0B35-1/2 \\
\hline 20 & $\mathrm{CKH}-08020$ & KB08A-0A51-9/10 & 43 & QPMHYB3 & KB08B-0B20-71/71 \\
\hline 21 & CKH-08021 & KB08A-0A51-13/14 & 44 & WH403(Local check) & WS \\
\hline 22 & CKH-08022 & KB08A-0A51-15/16 & 45 & $\mathrm{BH}-660$ (commercial) & \\
\hline 23 & CKH-08023 & KB08A-0A51-17/18 & & & \\
\hline
\end{tabular}

Table 1: List of QPM hybrids used in the Study. 
Where $h^{2}$ is Broad Sense Heritability; $\delta^{2} g$ is Genotypic Variance; and $\delta^{2} \mathrm{p}$ is Phenotypic Variance.

\section{Results and Discussion}

The analysis of variance showed highly significant variation among the genotypes $(\mathrm{p}<0.01)$ for characters such as days to $50 \%$ tasseling, ear height, plant count and yield (Table 2). This indicates that further mean separation is required for these characters to know which particular genotype is contributing for the differences observed (Table 2).

\section{Mean comparison for characters studied}

The mean values for studied character are given in Table 3. Detail and specific information about each character is given below.

Days to $50 \%$ tasseling: Days to $50 \%$ tasseling ranged from 70 to 86 days, the earliest and latest genotypes being $\mathrm{CKH}-08019$ and $\mathrm{BH}-660$, respectively.

The mean value for days to $50 \%$ tasseling was 77.37 days. Only 22 genotypes had shorter days to $50 \%$ tasseling than the mean value. Two hybrids (CKH-08016 and CKH-08019) showed significant difference with the commercial standard check (WH403) developed by CIMMYT. However, all the test genotypes tasseled earlier than the local check (BH-660). This is not, in fact, surprising as the test genotypes were developed for moisture-stressed and short rainy season ecologies while BH-660 is a late maturing hybrid developed for high rain fall areas. Thus, the 22 genotypes can be suitable for many agro-ecologies in Ethiopia with moisture-stress and/or short rainy season where BH-660 cannot perform well. Also, the genotypes have lysine and tryptophan contents higher than the local check; thereby fulfill the high protein requirements. Findings of earlier researchers revealed that there are significant differences between late maturing local checks and QPM hybrids in days to $50 \%$ tasseling [19-21].

Plant height: Plant height ranges from 156.8 to $261.4 \mathrm{~cm}$ (mean $189.7 \mathrm{~cm}$ ), the tallest genotype being the local check while the shortest genotype being $\mathrm{CKH}-08001$. Of all the genotypes, 19 of them were taller than the mean height whereas the rest were shorter. Interestingly, the height of the local check was statistically significantly greater than the other genotypes ( $\mathrm{p} \leq 0.01$; Table 3 ). XX QPM test genotypes yielded plant height greater than 2 meters.

Ear height: The mean ear height of the genotypes in this study was $84.2 \mathrm{~cm}$, the tallest being the local check $(147.2 \mathrm{~cm})$ and the shortest being CKH-08001 $(58.4 \mathrm{~cm})$. The study revealed high correlation between the plant height and ear height. This finding contradicts the report by where QPM hybrids were taller and had higher ear placement than non-QPM hybrids [22] (Table 3).

Plant count: The mean number of plants per plot stands at 13.52
( $\mathrm{SD}=1.64)$, the highest being 24 for $\mathrm{BH}-660$ and the lowest being 10 for $\mathrm{CKH}-08031$. Twenty five genotypes tested in the study have yielded plants per plot below the mean value. The local check yielded mean plant count (24.0) statistically significantly greater than that of all other genotypes ( $\mathrm{p} \leq 0.05)$. The mean values of three genotypes with highest plant count per plot, namely CKH-08008, CKH-08025 and CKH08005 are statistically significantly highest than the three genotypes with lowest plant count per plot, namely CKH-08031, CKH-08026 and $\mathrm{CKH}-08035$. The analyses revealed weak correlation between plant count and grain yield as the genotype with the lowest grain yield (CKH-08001) had higher number of plant count.

Grain yield: Grain yield per hectare ranged from the $20.8(\mathrm{CKH}-$ $08001)$ to 106.76 (BH-660) quintals. The overall mean grain yield per hectare was 36.48 quintals. Mean grain yields of majority of the genotypes were much lower than the overall yield per hectare; and the local check yielded statistically significantly greater mean yield than all entries. This finding is similar to the findings of Tulu et al. and Wannows et al. [23,24]. As indicated earlier, the QPM hybrids were early maturing and are not expected to perform like the plants of the late maturing check that exploits the full growing season. Interestingly, there were early flowering genotypes such as CKH-08005, CKH-08016, CKH-08020, CKH-08023, CKH-08024, CKH-08031, CKH-08038, and $\mathrm{CKH}-08040$ that yielded better mean grain yield compared to others including the commercial check. As stated earlier, the genotypes are primarily developed for moisture-stressed and short rainy season agro ecologies, thus were not able to exploit their full potential. Hence, it is difficult to underestimate their yielding ability. And yet, they are readily available sources of essential proteins for households and communities consuming maize as their principal daily food for economic and cultural reasons. The QPM varieties can also help farmers meet their food needs during a period of food shortage before the late maturing varieties were ready for harvest.

Hundred grains weight: The study revealed that the overall mean value for hundred grains weight was $27.64 \mathrm{~g}$, the highest mean hundred grains weight recorded for $\mathrm{BH}-660(42.9 \mathrm{~g})$ and the smallest for CKH-08003 and CKH-08014 (22.0 g). Of all the genotypes, 25 of them yielded mean hundred grains weight less than the overall mean. All early maturing genotypes with higher grain yield per hectare except CKH-08005 were found to have higher hundred grains weight than most genotypes. This, furthermore, gives some additional clue that these genotypes have to be privileged in further studies.

Number of kernel rows per ear: The mean number of kernel rows per year was 14.3 , the highest mean number kernel rows per ear being 16.8 for CKH-08007 the lowest being 12.8 for CKH-08034. Majority of the genotypes had 14 mean number kernel rows per ear. All genotypes with higher grain yield had lesser mean number of kernel rows per ear than the overall mean with the exception of CKH-08038 that

\begin{tabular}{|c|c|c|c|c|c|c|c|c|c|}
\hline \multirow[t]{2}{*}{ Source of Variation } & \multirow[t]{2}{*}{$d f$} & \multicolumn{8}{|c|}{$t-$ Values ( $p$ Values) } \\
\hline & & TS & PH & $\mathrm{EH}$ & PC & NRE & NGR & HGWt & Yield \\
\hline Replication & 1 & $6.068(0.325)$ & $1078.828(0.054)$ & $481.636(0.017)$ & $1.877(0.412)$ & $0.171(0.674)$ & $9.501(0.345)$ & $8.403(0.450)$ & $7.85(0.802$ \\
\hline Block & 16 & $19.197(0.000)$ & $609.886(0.027)$ & $232.786(0.004)$ & $2.620(0.512)$ & $0.895(0.532)$ & $22.124(0.039)$ & $17.053(0.331)$ & $130.580(0.423)$ \\
\hline Entry & 44 & $15.038(0.004)$ & $335.534(0.264)$ & $220.605(0.002)$ & $6.789(0.006)$ & $0.951(0.503)$ & $13.218(0.248)$ & $23.137(0.089)$ & $297.890(0.007)$ \\
\hline Error & 28 & 5.642 & 267.079 & 74.889 & 2.703 & 0.944 & 10.251 & 14.284 & 121.870 \\
\hline Total & 89 & & & & & & & & \\
\hline CV & & 3.07 & 8.62 & 10.28 & 12.16 & 6.78 & 9.70 & 13.67 & 30.26 \\
\hline
\end{tabular}

TS: Days to 50\% Tasseling; PH: Plant Height; EH: Ear Height; PC: Plant Count; NRE: Number of Kernel-Rows per Ear; NKR: Number of Kernels per Row; HGWt: Hundred Grains Weight; Numbers in Parenthesis indicate the Probability Values.

Table 2: Analysis of variance for evaluation of QPM hybrids 
Citation: Aman J, Bantte K, Alamerew S, Tolera B (2016) Evaluation of Quality Protein Maize (Zea mays L) Hybrids at Jimma, Western-Ethiopia. J Forensic Anthropol 1: 101.

Page 4 of 6

\begin{tabular}{|c|c|c|c|c|c|c|c|c|}
\hline Name & TS & PH & EH & PC & NRE & NKR & HGWt & Yield \\
\hline CKH-08001 & $82.0^{\mathrm{ba}}$ & 156.8 & $58.4^{\prime}$ & $14.5^{\mathrm{cb}}$ & 14.0 & 29.8 & 24.05 & $20.80^{h}$ \\
\hline CKH-08002 & $79.0^{\text {fbedcg }}$ & 173.9 & $84.8^{\text {fkcjeibhdg }}$ & $12.0^{\text {cebd }}$ & 13.0 & 31.3 & 27.15 & $33.88^{\text {fcendg }}$ \\
\hline CKH-08003 & $77.5^{\text {fbedcg }}$ & 174.2 & $68.0^{\mathrm{ij}}$ & $12.5^{\text {cebd }}$ & 14.0 & 30.3 & 22.00 & $26.03^{\text {fhg }}$ \\
\hline CKH-08004 & $80.5^{\text {bedc }}$ & 181.8 & $79.8^{\text {fkcjeihdg }}$ & $14.0^{\mathrm{cbd}}$ & 14.8 & 27.9 & 27.25 & $27.03^{\text {fhg }}$ \\
\hline CKH-08005 & $75.5^{\text {fedhcg }}$ & 198.1 & $91.3^{\text {fcebdg }}$ & $15.0^{\mathrm{b}}$ & 14.2 & 35.3 & 26.50 & $49.95^{\text {cebd }}$ \\
\hline CKH-08006 & $74.5^{\text {fing }}$ & 206.3 & $93.8^{\text {fcebd }}$ & $14.0^{\mathrm{cbd}}$ & 13.4 & 32.2 & 28.80 & $35.00^{\text {feendg }}$ \\
\hline CKH-08007 & $73.5^{\text {ing }}$ & 204.0 & $96.8^{\mathrm{cbd}}$ & $14.0^{\mathrm{cbd}}$ & 16.8 & 33.6 & 22.85 & $37.12^{\text {fcehdg }}$ \\
\hline CKH-08008 & $78.5^{\text {fbedcg }}$ & 188.1 & $80.5^{\text {fkcjeindg }}$ & $15.0^{\mathrm{b}}$ & 14.8 & 34.1 & 28.25 & $32.39^{\text {fcehdg }}$ \\
\hline CKH-08009 & $76.5^{\text {fbedhcg }}$ & 185.5 & $88.4^{\text {fceibhdg }}$ & $12.5^{\text {cebd }}$ & 14.6 & 33.6 & 26.65 & $39.86^{\text {fcendg }}$ \\
\hline CKH-08010 & $79.0^{\text {fbedcg }}$ & 176.1 & $68.1^{1 \mathrm{j}}$ & $13.0^{\text {cebd }}$ & 14.3 & 35.3 & 33.95 & $30.15^{\text {fehg }}$ \\
\hline СКН-08011 & $78.5^{\text {fbedcg }}$ & 170.8 & $70.2^{\mathrm{ing}}$ & $12.0^{\text {cebd }}$ & 14.2 & 34.5 & 27.25 & $27.16^{\text {fhg }}$ \\
\hline CKH-08012 & $77.5^{\text {fbedcg }}$ & 192.8 & $87.3^{\text {fceibhdg }}$ & $12.5^{\text {cebd }}$ & 14.6 & 36.5 & 29.05 & $39.36^{\text {fcendg }}$ \\
\hline CKH-08013 & $76.0^{\text {fedhcg }}$ & 188.7 & $77.5^{\text {feijhdg }}$ & $14.5^{\mathrm{cb}}$ & 13.6 & 34.3 & 29.55 & $34.13^{\text {fcehdg }}$ \\
\hline CKH-08014 & $78.5^{\text {fbedcg }}$ & 187.9 & $84.8^{\text {fceibhdg }}$ & $13.0^{\text {cebd }}$ & 14.8 & 30.3 & 22.00 & $24.17^{\mathrm{hg}}$ \\
\hline CKH-08015 & $77.0^{\text {fbedcg }}$ & 199.3 & $88.2^{\text {fceibhdg }}$ & $13.0^{\text {fceibhd }}$ & 14.2 & 34.2 & 28.20 & $35.12^{\text {feendg }}$ \\
\hline CKH-08016 & $71.0^{\text {in }}$ & 184.2 & $79.7^{\text {fkcjeindg }}$ & $14.5^{\mathrm{cb}}$ & 14.4 & 32.8 & 29.35 & $42.23^{\text {fcehdg }}$ \\
\hline CKH-08017 & $76.0^{\text {fedhcg }}$ & 184.2 & $77.3^{\text {feijhdg }}$ & $14.0^{\mathrm{cbd}}$ & 14.8 & 33.6 & 28.75 & $30.15^{\text {fehg }}$ \\
\hline CKH-08018 & $78.0^{\text {fbedcg }}$ & 171.0 & $70.8^{\mathrm{ijhg}}$ & $13.5^{\mathrm{cbd}}$ & 15.4 & 29.6 & 24.05 & $29.52^{\text {fehg }}$ \\
\hline CKH-08019 & $70.0^{i}$ & 189.3 & $83.8^{\text {feeibhdg }}$ & $13.0^{\text {cebd }}$ & 13.6 & 34.1 & 26.65 & $30.76^{\text {fcehdg }}$ \\
\hline CKH-08020 & $80.0^{\text {fbedc }}$ & 195.6 & $94.8^{\text {cebd }}$ & $12.5^{\text {cebd }}$ & 15.2 & 33.8 & 27.05 & $47.83^{\text {fcebdg }}$ \\
\hline CKH-08021 & $77.0^{\text {fbedcg }}$ & 192.7 & $79.5^{\text {fkcjeindg }}$ & $14.5^{\mathrm{cb}}$ & 14.0 & 33.8 & 29.30 & $27.77^{\text {fchg }}$ \\
\hline CKH-08022 & $81.0^{\mathrm{bdc}}$ & 187.9 & $79.4^{\text {fkcjeindg }}$ & $12.0^{\text {cebd }}$ & 15.0 & 32.7 & 26.00 & $31.76^{\text {fcehdg }}$ \\
\hline CKH-08023 & $75.0^{\text {fedhcg }}$ & 196.7 & $95.5^{\text {cebd }}$ & $14.0^{\text {cebd }}$ & 13.6 & 34.5 & 34.25 & $53.18^{\mathrm{cb}}$ \\
\hline CKH-08024 & $76.5^{\text {fbedhcg }}$ & 206.2 & $99.9^{b}$ & $12.5^{\mathrm{b}}$ & 14.4 & 31.6 & 28.20 & $43.97^{\text {fcebdg }}$ \\
\hline CKH-08025 & $76.5^{\text {fbedhcg }}$ & 187.8 & $85.6^{\text {fceibhdg }}$ & $15.0^{\mathrm{b}}$ & 14.6 & 32.3 & 27.50 & $29.39^{\text {fehg }}$ \\
\hline CKH-08026 & $76.5^{\text {fbedhcg }}$ & 196.6 & $89.4^{\text {fcebhdg }}$ & $11.0^{\text {cebd }}$ & 14.8 & 29.5 & 23.40 & $33.01^{\text {fcendg }}$ \\
\hline CKH-08027 & $77.5^{\text {fbedcg }}$ & 199.4 & $85.2^{\text {fceibdg }}$ & $14.5^{\mathrm{cb}}$ & 14.0 & 34.7 & 29.15 & $37.87^{\text {fcehdg }}$ \\
\hline CKH-08028 & $76.0^{\text {fedhcg }}$ & 199.1 & $88.3^{\text {fceibdg }}$ & $12.0^{\text {cebd }}$ & 14.0 & 31.5 & 24.85 & $36.62^{\text {fcehdg }}$ \\
\hline CKH-08029 & $81.5^{\mathrm{bac}}$ & 182.6 & $76.2^{\text {feijhdg }}$ & $12.5^{\text {cebd }}$ & 14.4 & 37.7 & 26.65 & $31.89^{\text {fcendg }}$ \\
\hline CKH-08030 & $81.0^{\text {bdc }}$ & 184.7 & $78.6^{\text {fceijhdg }}$ & $12.5^{\text {cebd }}$ & 14.6 & 35.4 & 26.15 & $37.87^{\text {fcehdg }}$ \\
\hline CKH-08031 & $77.5^{\text {fbedcg }}$ & 186.8 & $81.2^{\text {fceibhdg }}$ & $10.0^{\mathrm{e}}$ & 14.2 & 34.0 & 27.60 & $47.71^{\text {fcebdg }}$ \\
\hline CKH-08032 & $77.0^{\text {fbedcg }}$ & 199.2 & $101.50^{b}$ & $13.5^{\mathrm{cbd}}$ & 13.4 & 31.9 & 30.10 & $35.88^{\text {fcehdg }}$ \\
\hline CKH-08033 & $80.5^{\text {bedc }}$ & 163.6 & $68.30^{\mathrm{ijh}}$ & $13.5^{\mathrm{cbd}}$ & 13.6 & 31.9 & 26.30 & $24.79^{\mathrm{hg}}$ \\
\hline CKH-08034 & $78.5^{\text {fbedcg }}$ & 188 & $84.0^{\text {fceibhdg }}$ & $13.0^{\text {cebd }}$ & 12.8 & 32.3 & 27.85 & $26.41^{\text {fhg }}$ \\
\hline CKH-08035 & $75.5^{\text {fiedh }}$ & 205.8 & $82.1^{\text {fceibhdg }}$ & $11.5^{\text {ced }}$ & 13.6 & 37.4 & 28.00 & $31.39^{\text {fcendg }}$ \\
\hline CKH-08036 & $76.5^{\text {fbedhcg }}$ & 202.6 & $92.5^{\text {fcebd }}$ & $14.5^{\mathrm{cb}}$ & 14.6 & 30.9 & 25.55 & $33.38^{\text {fcehdg }}$ \\
\hline CKH-08037 & $78.0^{\text {fbedcg }}$ & 174.8 & $73.5^{\text {fijhg }}$ & $14.5^{\mathrm{cb}}$ & 14.8 & 29.9 & 23.30 & $27.41^{\text {fehg }}$ \\
\hline CKH-08038 & $74.5^{\text {fing }}$ & 192.9 & 88. $1^{\text {fceibdg }}$ & $14.0^{\mathrm{cbd}}$ & 15.6 & 35.2 & 29.90 & $52.44^{\mathrm{cbd}}$ \\
\hline CKH-08039 & $74.5^{\text {fing }}$ & 191.5 & $78.2^{\text {feijhdg }}$ & $12.5^{\text {cebd }}$ & 13.8 & 33.4 & 26.75 & $34.38^{\text {fcehdg }}$ \\
\hline CKH-08040 & $73.5^{\text {ing }}$ & 203.8 & $95.8^{\mathrm{cbd}}$ & $13.0^{\mathrm{cb}}$ & 14.2 & 34.1 & 33.00 & $61.54^{b}$ \\
\hline QPMHYB1 & $77.0^{\text {fbedcg }}$ & 187.3 & $77.9^{\text {feijhdg }}$ & $14.0^{\mathrm{cbd}}$ & 14.0 & 32.3 & 24.95 & $26.03^{\text {fhg }}$ \\
\hline QPMHYB2 & $\underline{79.5^{\text {fbedcg }}}$ & 168.7 & $77.0^{\text {feijhdg }}$ & $14.0^{\mathrm{cbd}}$ & 14.2 & 34.3 & 25.50 & $30.64^{\text {fcehdg }}$ \\
\hline QPMHYB3 & $78.0^{\text {fbedcg }}$ & 177.5 & $74.5^{\text {feijhg }}$ & $14.0^{\mathrm{cbd}}$ & 14.4 & 30.3 & 28.90 & $24.54^{\mathrm{hg}}$ \\
\hline WH403 & $77.5^{\text {fbedcg }}$ & 188.2 & $83.9^{\text {fceibhdg }}$ & $13.0^{\text {cebd }}$ & 14.4 & 34.7 & 28.45 & $42.10^{\text {fcebhdg }}$ \\
\hline $\mathrm{BH}-660$ & $86.5^{a}$ & 261.4 & $147.2^{\mathrm{a}}$ & $24.0^{a}$ & . & . & 42.90 & $106.76^{a}$ \\
\hline Mean & 77.37 & 189.7 & 84.17 & 13.52 & 14.31 & 37.7 & 27.64 & 36.48 \\
\hline CV (\%) & 3.07 & 8.62 & 10.28 & 12.16 & 6.78 & 9.7 & 13.67 & 30.26 \\
\hline $\operatorname{LSD}(0.05)$ & 2.05 & NS & 17.72 & 3.368 & NS & NS & NS & 22.613 \\
\hline
\end{tabular}

NRE: Number of Kernel-Rows per Ear; NKR: Number of Kernels per Row; HGWt: Hundred Grains Weight.

NS: Not Significant; TS: Days to 50\% Tasseling; PH: Plant Height; EH: Ear Height; PC: Plant Count.

Table 3: Mean performance QPM hybrids evaluated at Eladalle (Jimma) for different characters.

yielded the second highest mean number of kernel rows per ear. CKH08016, CKH-08020, CKH-08024, and CKH-08038 had statistically significantly greater mean numbers of kernel rows per ear than that of commercial check.

Number of kernels per row: The overall mean number of kernels per row was 33.02; the maximum mean number of kernels per row being 37.7 for $\mathrm{CKH}-08029$ and the minimum being 27.9 for $\mathrm{CKH}-8004$.
Among the genotypes yielding high grain yield, only CKH-08016 and CKH-08024 had a mean number of kernels below the overall mean, though all variations are non-significant at $\mathrm{p} \leq 0.05$.

Phenotypic and genotypic variances and their coefficients of variations

Estimated variance components (phenotypic and genotypic), 
Citation: Aman J, Bantte K, Alamerew S, Tolera B (2016) Evaluation of Quality Protein Maize (Zea mays L) Hybrids at Jimma, Western-Ethiopia. J Forensic Anthropol 1: 101.

Page 5 of 6

\begin{tabular}{|c|c|c|c|c|c|c|}
\hline Variable & Mean (SD) & GCV (\%) & PCV (\%) & $\delta^{2} \mathbf{p}$ & $\delta^{2} \mathbf{g}$ & $\mathbf{H}^{2}$ \\
\hline TS & 77.37 (3.66) & 2.25 & 4.74 & 13.48 & 3.028 & 0.2247 \\
\hline $\mathrm{PH}$ & $189.67(13.89)$ & 7.17 & 10.23 & 379.61 & 186.58 & 0.4915 \\
\hline $\mathrm{EH}$ & $84.17(11.50)$ & 12.55 & 18.55 & 243.79 & 111.48 & 0.4573 \\
\hline PC & $13.52(1.64)$ & 11.62 & 16.77 & 5.143 & 2.470 & 0.4805 \\
\hline NRE & $14.31(0.69)$ & 15.79 & 16.57 & 5.363 & 4.876 & 0.9092 \\
\hline NKR & $33.02(1.37)$ & 16.72 & 17.57 & 32.112 & 29.127 & 0.9071 \\
\hline HGWt & $27.64(2.15)$ & 11.66 & 13.89 & 15.601 & 10.997 & 0.7049 \\
\hline Yield & $37.66(6.87)$ & 31.38 & 36.38 & 186.9 & 139.66 & 0.7473 \\
\hline
\end{tabular}

GCV: Genotypic Coefficient of Variation; PCV: Phenotypic Coefficient of Variation; $\delta^{2} \mathrm{p}$ : Phenotypic Variance; $\delta^{2} \mathrm{~g}$ : Genotypic Variance; $\mathrm{H}^{2}$ : Heritability in Broad Sense.

Table 4: Components of variance, coefficient of variations and heritability of characters.

phenotypic coefficient of variability, genotypic coefficient of variability, broad sense heritability of the characters investigated in the present study are presented in Table 4.

Phenotypic and genotypic variances: Analyses of estimated components of variances showed the highest phenotypic variance in plant height $\left(\delta^{2} \mathrm{p}=379.61\right)$ followed by ear height $\left(\delta^{2} \mathrm{p}=243.79\right)$ whereas the minimum phenotypic variance was observed for plant count $\left(\delta^{2} \mathrm{p}=5.14\right)$. This implies that there is great variation in the test materials with regard to height of plants and ear height. Phenotypic variance is sum total of genotypic variance, environmental variance, and the interaction of effect of the two $(\mathrm{G} \times \mathrm{E})$. But, as the study was carried out in a single location, the contribution $\mathrm{G} \times \mathrm{E}$ is considered negligible. Thus, genotypes and the environment shall be accountable to the observed phenotypic variations. It can, then, be claimed that the effect of the environment on the total variance in plant height and ear height has to be high as the genotypic variances for the traits are relatively less compared to the phenotypic variation.

The contribution of genotypic variance $\left(\delta^{2} \mathrm{~g}=3.03\right)$ in the phenotypic variance $\left(\delta^{2} \mathrm{p}=13.48\right)$ for days to $50 \%$ tasseling was also low, where the contribution of the environment stands at 10.45. Similar findings were reported by Upadhyay et al. [25] based on field evaluation of QPM genotypes under rain-fed conditions. The workers observed lower contributions of genetic variance for the total observable variation with regard to days to $50 \%$ tasseling, plant height, and ear height. It was also reported that smaller contribution of genotypic variance to the total phenotypic variance in regard to ear height and plant height [26]. For the rest of traits, the phenotypic variances were largely contributed by the genotypic variances indicating a relatively smaller effect of environmental. Where phenotypic variances are primarily dependent on the genotypes, the selection of varieties with desirable phenotype ensures the selection of better genotype. Genetic variability is the core of plant breeding because proper management of diversity can produce permanent gains in the performance of plants and can buffer against seasonal fluctuations $[27,28]$ (Table 4).

Phenotypic and Genotypic Coefficient of Variations: The levels of variability observed among the genotypes were assessed based on the genetic and phenotypic coefficients of variation (Table 4). PCV for the studied characters ranges from $4.74 \%$ (for Days to $50 \%$ Tasseling) to $36.38 \%$ (for Yield per Hectare) whereas the GCV ranged from $2.25 \%$ (for Days to 50\% Tasseling) to 31.38\% (for Grain Yield per Hectare). The PCV and GCV values were high for Ear Height, Plant Count, Number of Kernel-Rows per Ear, Number of Kernels per Row and Grain Yield per Hectare. These imply the presence of considerable level of observable variations within the genotypes in regard to these traits. Hence, there are good opportunities for improving the traits among the tested genotypes because of wide scope for selection. The highest GCV for Grain Yield (33.6\%) and the lowest for Days to Anthesis (5.2\%) on QPM inbred lines and PVC ranging from 5.8\% for Days to Anthesis to 43.4\% for Grain Yield was reported [29], quite similar to the findings of the present study. Relatively higher estimates of GCV for Grain Yield per Plant, Ear Height, and Grains per Row, Hundred Grains Weight, and Grain Yield showing activities are effective with these traits [3032].

\section{Broad sense heritability}

The Broad Sense Heritability ranged from 0.2247 (for Days to $50 \%$ Tasseling) to 0.9092 (for Number of Kernel-Rows per Ear). Traits with moderate Broad Sense Heritability estimates include Plant Height (0.4915), Ear Height (0.4573) and Plant Count (0.480) (Table 4). This observation implies that the profound phenotypic variations are not due the genotype but due to the environment. Hence, as such variations are not heritable the selection of the characters bringing the variations is not efficient because the true performance of the genotypes will not be consistent along successive generations. Lower heritability for Days to $50 \%$ Tasseling and Plant Height in double cross hybrids was also reported [33]. Likewise, Rafique et al. [34] reported moderate Broad Sense Heritability (0.396) for Ear Height in 3-way crosses hybrid. As shown in Table 3, we observed higher Broad Sense Heritability for Number of Kernel-Rows per Ear (0.9092), Number of Kernels per Row (0.9071), 100-Grains Weight (0.7049), and Grain Yield (0.7473) implying that these traits are highly heritable and selection would be fairly easy and effective [34,35]. Selection for a character with high Broad Sense Heritability is fairly easy as the effect of the environment on the genotype is believed to be minimal [36]. Values of Broad Sense Heritability alone would not be sufficient parameters in selecting the best individuals [37]. In this regard Mulatu et al. [38] have suggested that genetic coefficients of variation together with heritability estimates would give the best picture of genetic advances in selection. Hence, traits exhibiting high genotypic coefficients of variation and high heritability would be preferred in selection. We observed higher values of GCV and $\mathrm{H}^{2}$ for Number of Kernel-Rows per Ear, Number of Kernels per Row, 100-Grains Weight, and Grain Yield. However, the Number of Kernel-Rows per Ear had negative and statistically significant genotypic correlation with Grain Yield while the Number of Kernels per Row had non-significant genotypic correlation with the same trait. Hence, it is safe to suggest the use of 100-Grains Weight as selection criteria in crop improvement studies.

\section{Conclusion}

Based on the field evaluation, although the local check outperformed all the test materials, genotypes such as CKH-08005, CKH-08016, CKH-08020, CKH-08023, СKH-08024, СKH-08031, СKH-08038 and $\mathrm{CKH}-08040$ had better performance than the others in terms of 
Citation: Aman J, Bantte K, Alamerew S, Tolera B (2016) Evaluation of Quality Protein Maize (Zea mays L) Hybrids at Jimma, Western-Ethiopia. J Forensic Anthropol 1: 101

Page 6 of 6

grain yield. The lower yield of the test materials was due to the fact that the genotypes were early maturing and are primarily developed for moisture stress areas and are not expected to outperform the local check which is a late maturing hybrid.

\section{References}

1. United States Department of Agriculture [USDA] (2005) Germplasm Resources Information Network. Beltsville: USDA

2. Ellneskog-Staam P, Loaisiga HC, Merker A (2007) Chromosome C-banding of the teosinte Zea nicaraguensis and comparison to other Zea species. Heredita 144: $96-101$

3. Prasanna BM, Vasal SK, Kassahun B, Singh NN (2001) Quality protein maize. Current Science 81: 1308-1319.

4. Vasal SK (2002) Quality protein maize: Overcoming the hurdles. In: Katak PK, Babu SC (eds.) Food systems for improved human nutrition: Linking agriculture, nutrition and productivity . Food Products Press: An Imprint of the Haworth Press, Inc., pp: 193-227.

5. Gibbon BC, Larkins BA (2005) Molecular genetics approaches to developing quality protein maize. Trends in Genetics 21: 227-233.

6. Mertz ET, Bates LS, Nelson OE (1964) Mutant gene that changes protein composition and lysine content of maize endosperm. Science 145: 279-280.

7. Sofi PA, Wani SA, Rather AG, Wani SH (2009) Quality protein maize (QPM): Genetic manipulation for the nutritional fortification of maize. Journal of Plant Breeding and Crop Science 1: 244-253.

8. Ignjatovic MD, Stankovic G, Markovic K, Lazic-Jancic V, Denic M (2008) Quality protein maize (QPM). Genetika 40: 205-214.

9. Vasal SK, Villegas E, Tang CY, Werder J, Read M (1984) Combined use of two genetic systems in the development and improvement of quality protein maize. Kulturpflanze 32: 171-185.

10. Bjarnason M, Vasal SK (1992) Breeding of quality protein maize. Plant Breeding Review 9: 181-216.

11. Dreher K, Morris M, Khairallah M, Ribaut JM, Pandey S, et al. (2000) Is markerassisted selection cost-effective compared to conventional plant breeding methods? The case of quality protein maize. In Proceedings of the fourth annual conference of the International Consortium on Agricultural Biotechnology Research: the Economics of agricultural biotechnology, Ravello, Italy.

12. Vasal SK (2000) Quality protein maize story. In Proceedings of workshop on improving human nutrition through agriculture, 1-16. Los Banos, Philippines: International Rice Research Institute and International Food Policy Research Institute.

13. EARO (2004) Directory of released crop varieties and their recommended cultural practices. Proceedings of Ethiopian Agricultural Research Organization.

14. CIMMYT (2008) More nutritious maize boosts growth of children in rural Ethiopia. CIMMYT e-News.

15. MoARD (Ministry of Agriculture and Rural Development) (2008) National maize strategic plan. Ethiopian Ministry of Agriculture and Rural Development, Addis Ababa, Ethiopia. Unpublished document.

16. BPEDORS (Bureau of Planning and Economic Development of Oromia Regional State) (2000) Physical and Socioeconomic profile of 180 districts of Oromia Region. Oromia State Physical Planning Development, Finfinne, Ethiopia.

17. SAS (2008) Statistical Analysis Software. SAS Inc

18. Pascal International Software solution (1994) GENRES: Statistical package for genetic researchers, Version 7.01. Washington DC, USA.

19. CIMMYT, EARO (1999) Maize production technology for the future. In Proceedings of the sixth eastern and southern Africa regional maize conference on challenges and opportunities, Addis Ababa, Ethiopia.

20. Bello OB, Olaoye G (2009) Combining ability for maize grain yield and other agronomic characters in a typical southern guinea savanna ecology of Nigeria. African Journal of Biotechnology 8: 2518-2522.

21. Vasal SK, Srinivasan G, Pandey S, Gonzalez F, Crossa J, et al. (1993) Heterosis and combining ability of CIMMYT's quality protein maize germplasm
I: Lowland tropical. Crop Science 33: 46-51.

22. Bhatnagar S (2004) Phenotypic and Genotypic characterization of high lysine maize. PhD thesis, Texas A\&M University, USA.

23. Tulu L, Worku M, Seboksa G, Abdurehman J, Tuna H, et al. (2001) Quality protein maize research in Ethiopia. In Proceeding of the second national maize workshop on enhancing the contribution of maize to food security in Ethiopia Addis Ababa, Ethiopia.

24. Wannows AA, Azzam HK, AL-Ahmad SA (2010) Genetic variances, heritability correlation and path coefficient analysis in yellow maize crosses (Zea mays $\mathrm{L}$ ). Agriculture and Biology Journal of North America 1: 630-637.

25. Upadhyay SR, Gurung DB, Paudel DC, Koirala KB, Sah SN, et al. (2009) Evaluation of quality protein maize (QPM) genotypes under rainfed Mid Hil environments of Nepal. Nepal Journal of Science and Technology 10: 9-14.

26. Akbar M, Shakoor MS, Hussein A, Sarwar M (2008) Evaluation of maize 3-way crosses through genetic variability, broad sense heritability, characters association and path analysis. Journal of Agricultural Science 46: 39-45.

27. Welsh JR (1981) Fundamentals of plant genetics and breeding. New York, NY: John Willey and Sons.

28. Sharma JR (1998) Statistical and biometrical techniques in plant breeding. New Delhi, India: New Age International (P) Limited Publishers.

29. Gissa DW (2008) Genotypic variability and combining ability of quality protein maize inbred lines under stress and optimal conditions. $\mathrm{PhD}$ thesis, University of Free State, Republic of South Africa.

30. Mahmood Z, Ajmal SU, Jilani G, Irfan M, Ashraf M (2004) Genetic studies for high yield of maize in Chitral Valley. International Journal of Agriculture and Biology 6: 788-789.

31. Rafiq CM, Rafique M, Hussain A, Altaf M (2010) Studies on heritability, correlation and path analysis in maize (Zea mays L). Journal of Agricultural Research 48: 35-38.

32. Singh BD (2005) Plant breeding: Principles and methods (7th Edn.), New Delhi, India: Kalyani Publishers.

33. Singh RK, Chaudhry BD (1985) Biometrical methods in quantitative genetic analysis. New Delhi, India: Kalyani Publishers.

34. Rafique M, Hussain A, Mahmood T, Alvi AW, Alvi MB (2004) Heritability and interrelationships among grain yield and yield components in maize (Zea mays L.). International Journal of Agriculture and Biology 06: 1113-1114.

35. Farnham DE, Benson GO, Pearce RB (2003) Corn perspective and culture. In Corn: Chemistry and technology, edited by White PJ, Johnson LA, St. Paul, Minnesota: American Association of Cereal Chemicals.

36. Assefa K, Ketema S, Tefera H, Nguyen HT, Blum A, et al. (1999) Diversity among germplasm lines of the Ethiopian cereal tef (Eragrostis tef (Zucc.) Trotter). Euphytica 106: 87-97.

37. Johnson HW, Robinson HF, Comstock RE (1955) Estimates of genetic and environmental variability in soybeans. Agronomy Journal 47: 314-318.

38. Mulatu K, Bogale G, Tolessa B, Worku M, Desalegne Y, et al. (1993) Maize production trends and research in Ethiopia. In Proceedings of the first national maize workshop of Ethiopia, editors B. Tolessa B, Ransom JK, Addis Ababa Ethiopia: IAR/CIMMYT. 